This is a post-print version. Please cite as:

Gómez, L. E., Schalock, R. L., \& Verdugo, M. A. (2019). The role of logic models and moderator and mediator variables in the field of intellectual disability. Journal of Developmental and Physical

Disabilities. Advance online publication. https://doi.org/10.1007/s10882-019-09702-3

\title{
The Role of Moderators and Mediators in Implementing and Evaluating Intellectual and Developmental Disabilities-Related Policies and Practices
}

\begin{abstract}
Issues. This article describes a comprehensive framework for incorporating moderator and mediator variables in program logic models and theory development as a useful way to better implement and evaluate policies and practices in the field of intellectual and developmental disabilities related (IDD). Findings. Firstly, an overview of [program] logic models in the field of IDD is provided. Secondly, we present the role of moderator and mediator variables in program logics models. Thirdly, the role of moderators and mediators is explained in relation to outcomes through a systematic review in the Web of Science. Fourthly, a discussion about the role that moderator and mediator variables play in theory development is provided. Fifthly, a comprehensive framework for incorporating moderator and mediator variables into program logic models is proposed. This comprehensive framework involves testing specific relations between well-defined and operatized moderator and/or mediator variables that may influence and impacts policies and practices' outcomes. Conclusions. When mediators and moderators are considered and included in program logic models, the effect of interventions, practices and policies can be better understood and therefore enhanced.
\end{abstract}

\section{Keywords}

Program Logic Models; Moderators; Mediators; Theory Development; Intellectual and Developmental Disabilities. 


\section{The Role of Moderators and Mediators in Implementing and Evaluating Intellectual and Developmental Disabilities-Related Policies and Practices}

Logic models, with their input, throughput, and output/outcome components, are increasingly being used as an organizing framework in the field of intellectual and developmental disabilities (IDD). Specific uses of logic model frameworks have been published in reference to program development, implementation, and evaluation (Schalock \& Verdugo 2012a); operations management (Schalock, Verdugo, \& Lee 2016); personal support plan development, implementation, and evaluation (Schalock, Thompson, \& Tassé 2018); organization transformation (Schalock, Verdugo, \& van Loon 2018); evidence-based practices (Schalock, Verdugo, \& Gómez 2011, 2017); social entrepreneurship (De Ruysscher et al. 2016); and policy development, implementation, and evaluation (Claes, Ferket, Vandevelde, Verlet, \& De Maeyer 2017; Schalock \& Verdugo, 2012b; Shogren, Luckasson, \& Schalock 2017; Verdugo et al. 2017).

The value of program logic models relates to their ability to articulate the operative relationships among program services, processes or activities, and effects. Thus, they provide a basis for scientific explanation and prediction. For example, program logic models enable organizations to: (a) understand what must be done to achieve the desired short term effects, but continue to focus on the long term impacts of their services and supports; (b) identify critical factors that can impact short term effects and long term impacts; (c) recognize critical players /stakeholders whose cooperation/ partnering is key to success; (d) show the intermediate effect of short term effects on long term impacts; (e) identify core processes so that re-engineering, quality improvement, and performance enhancement can take place; (f) provide a framework 
for analyzing alternative strategies for achieving the desired end-results; and (g) help stakeholders understand the sequence of events and processes from inputs through short term effects and long term impacts. In this regard, logic models are a vital tool in explanation, prediction, evaluation, and program development (Kaplan \& Garrett 2005; Millar, Simeone, \& Carnevale 2001; Schalock \& Verdugo 2012a).

In addition, program logic models are increasingly being used as a tool for empirically-based theories and theory driven evaluations. They allow going beyond conceptual frameworks — collection of important concepts and variables and suggested relationships among them — by empirically testing what the influencing factors are. In other words, conceptual frameworks offer a specific approach to study a phenomenon or construct. Frequently, there are specific and testable claims or propositions attached to those conceptual frameworks. In such cases, as Hansen, Alkin, and Wallace (2013) state, "it is appropriate to consider the approach, assumptions, and claims as together constituting a theory of evaluation" (p. 35). Thus, a logic model provides a helpful tool for depicting how these elements work together as a theory.

Although the utility of program logic models has proliferated over the past three decades through their use in the planning and evaluation of various types of human service programs, the inclusion of moderator and mediator variables in those models is still a challenge to policies and practices in the IDD field (Farmer 2012). Actually, moderator and mediator analyses are extremely sparse in the IDD field research although it is not certain why researchers in this field have been relatively slow to adopt their search. Among the main potential obstacles that may have inhibited their use are that the distinction between both moderators and mediators is often confusing together with relatively small samples and a lack of knowledge about their utility and mathematical determination (Farmer 2012). However, as human service programs and 
policies respond to the increasing need to demonstrate their effectiveness and efficiency, knowledge about the role that moderator and mediator variables play in service and supports delivery, outcome evaluation, and quality improvement becomes essential (Chen 2004; Davies 2004; Wasserman 2010).

To address this challenge, the purpose of this article is to demonstrate how an understanding of both logic models and moderator or mediator variables can be used in implementing and evaluating IDD-related policies and practices scientific given their important role in explanation and prediction. The article is divided into six sections. In the first section, we describe the use of logic models in the field of IDD. In the second section, we discuss the role of moderator and mediator variables in program logic models. The role of moderator and mediator variables on outcomes are explained in the article's third section. The fourth section is focused on addressing the role of moderators and mediators in theory development. Finally, a comprehensive framework for incorporating moderator and mediator variables into program logic models is presented in the fifth section. The article concludes with suggested future steps. Throughout the article, the following definitions are used:

- Logic model: A systematic process that aligns four identified program components: input, process, short-term effects, and long-term impacts.

- Moderator variable: A variable that alters the relation between two variables, and thus modifies the form or strength of the relation between an independent and dependent variable. A moderator effect is an interaction in which the effect of one variable is dependent on the level of the other.

- Mediator variable: A variable that explains the relation between an independent variable and an outcome, exhibiting indirect causation, connection, or relation. A 
mediating effect is created when a third factor intervenes between the independent variable and the dependent variable.

\section{The Use of Logic Models in the Field of IDD}

\section{Their Value}

Logic models (frequently referred to as program logic models) are highlighted as worthwhile means of building understanding and summarizing the theory of how a program, practice, or intervention works, since it enables investigators to analyze the linkages between the services and supports provided and the outcomes resulting from those services and supports (Bradley 2013; Rogers 2008). A program logic model serves to simplify a complex phenomenon by means of these core elements (i.e., activities and outcomes), but it also focuses on the underlying assumptions, context, and external factors that may impact a program's success (Mark 2008; Owen 2006; Rogers, 2008; Taylor-Powell \& Henert 2008). In this sense, learning about personal and contextual variables that might moderate or mediate the relationships between activities and outcomes depicted in a program logic model becomes essential.

\section{Their Components}

As depicted in Figure 1, program logic model components include inputs, processes, short-term effects related to personal outcomes and organization outputs, and long-term impacts. Input variables include targeted individuals, [components of] of the provider system, and contextual variables; process variables involve individual support strategies, organization services, and contextual variables; short term effects are measured on the basis of personal outcomes and organization outputs; and long-term impacts encompass social-economic position, health status and subjective well-being. 

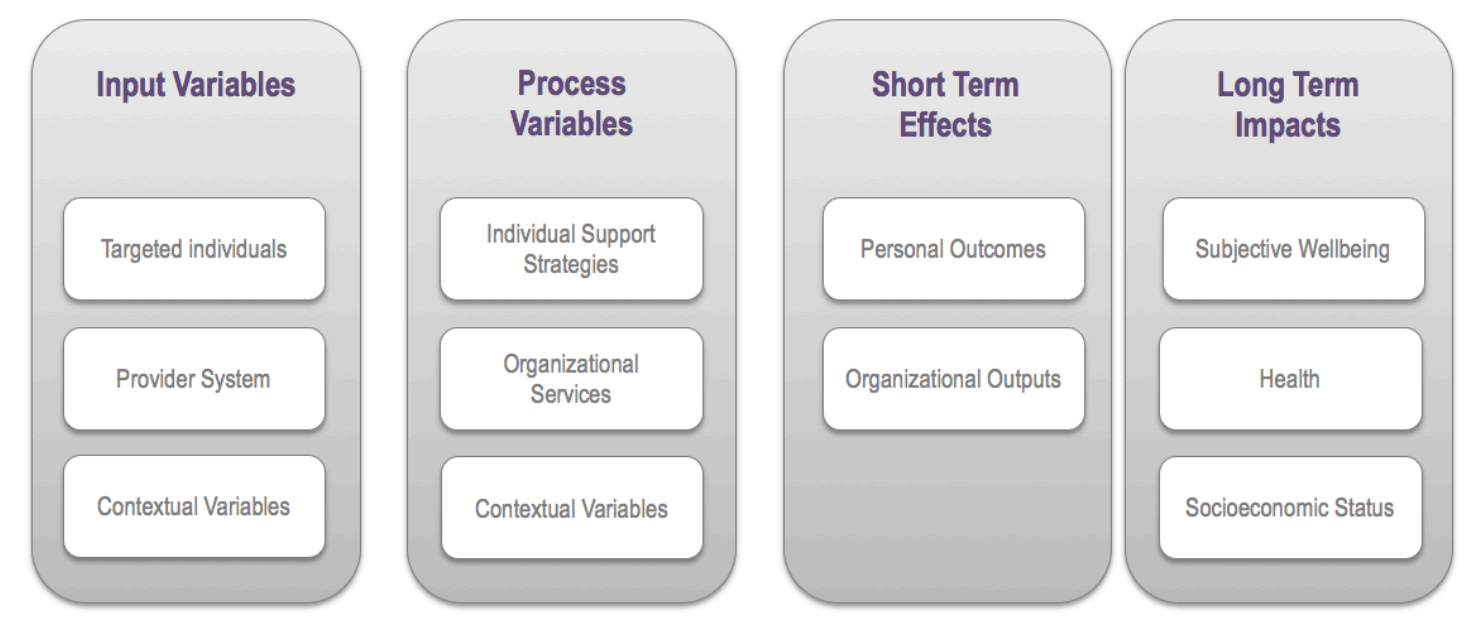

Figure 1. Program logic model in the field of IDD.

Within the short-term effect component of the model depicted in Figure 1, personal outcomes refer to the benefits to program recipients that are the result, directly or indirectly, of program services and supports. Frequently, these personal outcomes are defined and measured on the basis of core quality of life domains (Gómez, Arias, Verdugo \& Navas, 2012; Gómez \& Verdugo 2016; Schalock, Keith, Verdugo, \& Gómez 2010; Schalock \& Verdugo 2012a, 2012b; Verdugo, Navas, Gómez, \& Schalock 2012). In distinction, organizational outputs refer to the products that result from the resources a program uses to achieve its goals and objectives, and the actions/processes implemented by an organization to produce these products (Gómez, Verdugo, Arias, Navas \& Schalock, 2013; Schalock 2018; Verdugo 2018). Frequently, organizational outputs are defined and measured on the basis of effectiveness and efficiency indices based on four performance-based perspectives: that of the customer, and those of the organization's growth, financial analyses, and internal processes (Schalock \& Verdugo 2013). 


\section{The Role of Moderator and Mediator Variables in Program Logic Models}

In a program logic model, direct specific causal relations can be tested (i.e., relationships between independent variables and dependent variables). When mediators and moderators are considered and included in the model, the effect of external third variables can be explored, and the effect of interventions can be better understood and therefore enhanced. To this end, PROCESS — a versatile modeling tool freely-available for SPSS - and structural equation modeling techniques (e.g., MPlus, LISREL, AMOS, etc.) are increasingly being used to determine and show in diagrams the role that moderator, mediator, and latent variables play in both operationalizing a program logic model and explaining the influence of input and process variables on short-term effects and long-term impacts (Hayes, Montoya, \& Rockwood 2017). As discussed in the following sections, moderator variables influence input and process variables, whereas mediator variables influence short-term effects and long-term impact.

\section{Moderator Variables}

Moderator variables are critical for evaluating the generalizability of research findings and determining the relevant role of the variable(s) in program development, implementation, and evaluation and in theory construction (Farmer 2012). Theory may be used to predict moderator effects, but in other cases moderators may reflect a purely exploratory search for different relations across subgroups (MacKinnon 2008).

A moderator variable is defined as a variable that alters the relation between two variables and thus modifies the form or strength of the relation between an independent and a dependent variable (Baron \& Kenny 1986; Farmer 2012; Frazier, Tix, \& Barron 2004; Hair, Black, Babin, Anderson \& Tatham, 2006). A moderator effect is an interaction in which the effect of one variable is dependent on the level of the other; in 
other words, it helps answer what an effect depends upon (Farmer 2012) or for which groups does an intervention work (MacKinnon 2011). The moderator must display a significant interaction with the independent variable in predicting the dependent variable.

Moderator variables can be continuous or categorical, although a categorical moderator variable is often the easiest to interpret. Examples include a factor in experimental manipulation, representing random assignment to levels of the factor; a variable that is not manipulated, such as gender or age; or subgroups for which the treatment or intervention is more or less effective for a particular group.

\section{Mediator Variables}

A mediator variable influences the relation between an independent variable and an outcome, exhibiting indirect causation, connection, or relation (Baron \& Kenny 1986; Farmer 2012). Mediator variables are crucial in many fields because they allow us to understand the process by which two variables are related. For this reason, they are centrals to study the efficiency of interventions in human services. A mediating effect is created when a third factor intervenes between the independent variable and the dependent variable (Hair et al. 2006; MacKinnon 2008). As discussed by Farmer (2012) and MacKinnon (2011), a mediating effect explains how an intervention works. More specifically, it explains how the independent variable affects the mediator, which in turns impacts the dependent variable in a specific and predictable way. Thus, the intervention is expected to change mediating variables and the change in the mediating variables will cause changes in the outcome expected.

As it has been described by MacKinnon $(2008,2011)$, there are many reasons for including mediating variables in a research study since they allow: (a) manipulation 
check (i.e., checking whether the intervention produced a change in the mediation variable); (b) program improvement (i.e., identifying successful and unsuccessful interventions, practices or policies components); (c) measurement improvement (i.e. tools for assessing the mediators may not be valid or reliable enough to detect changes); (d) detecting delayed program effects (i.e., if the intervention does not have effect on the outcomes but it does on the mediator variable); (e) evaluating the process of change (i.e., provides information about the process by which the intervention achieves its effects on outcome (i.e., if critical components of interventions are identified and ineffective components are removed).

\section{The Influence of Moderator and Mediator Variables on Outcomes}

\section{Moderator Variables}

Although moderators are key in understanding how and why relations exist between variables, they have not been extensively studied in the field of IDD (Farmer 2012). With the aim of illustrating this lack of research and identifying those variables that are most often tested as moderators of outcomes for people with IDD, a systematic review was conducted on the Web of Science (September, 2018). First, we combined the keywords 'moderator' AND 'intellectual disability' in the field 'Title' AND 'program logic model' in the field 'Topic' without any timespan restriction but the search found no records. In a second less restrictive search, we only used the descriptors 'moderator' AND 'disability' in the field 'Title' without any timespan restriction. This last search yielded only 24 results: all of them published from 2007 to date. Most of the studies were conducted in the USA $(n=9)$ and published in English $(n=22)$. Among them, 14 were eliminated for several reasons: they were reviews or meta analyses $(n=3)$ or meeting abstracts $(n=3)$; they were focused on relatives or staff providing supports to 
people with disabilities $(n=5)$; they did not find any moderation effect $(n=2)$; or it was impossible to reach the full text nor abstract $(n=1)$. In this way, only 10 articles allowed the authors to analyze moderation relationships. As can be seen in Table 1, most of the relationships were stablished between disability and subjective wellbeing or quality of life. The moderator most frequently studied was social support. Other moderators, such as gender, age, self-esteem or problem-solving coping were also reported.

Table 1. Articles with moderation effects in the disability field.

\begin{tabular}{|c|c|c|c|c|c|}
\hline Reference & $\begin{array}{l}\text { Dependent } \\
\text { Variable }\end{array}$ & $\begin{array}{l}\text { Independent } \\
\text { variable }\end{array}$ & Moderator & Sample & Data analyses \\
\hline $\begin{array}{l}10.1080 / 09638 \\
288.2017 .1331 \\
380\end{array}$ & $\begin{array}{l}\text { Subjective } \\
\text { well-being }\end{array}$ & $\begin{array}{l}\text { Perceived } \\
\text { discrimination }\end{array}$ & $\begin{array}{l}\text { Perceived } \\
\text { social } \\
\text { support }\end{array}$ & $\begin{array}{l}\text { Physical } \\
\text { disabilities }\end{array}$ & $\begin{array}{l}\text { Hierarchical } \\
\text { multiple } \\
\text { regression }\end{array}$ \\
\hline $\begin{array}{l}10.1590 / 1413- \\
81232015211 \\
01012015\end{array}$ & Quality of life & $\begin{array}{l}\text { Functional } \\
\text { disability }\end{array}$ & Family type & $\begin{array}{l}\text { Physical } \\
\text { disabilities }\end{array}$ & $\begin{array}{l}\text { Linear multiple } \\
\text { regression }\end{array}$ \\
\hline $\begin{array}{l}\text { Sexton, King- } \\
\text { Kallimanis, } \\
\text { Layte, \& } \\
\text { Hickey (2015) }\end{array}$ & Quality of life & Disability & $\begin{array}{l}\text { Supportive } \\
\text { partner and } \\
\text { relatives } \\
\text { Personal } \\
\text { religiosity }\end{array}$ & $\begin{array}{l}\text { Older } \\
\text { adults }\end{array}$ & $\begin{array}{l}\text { Conditional } \\
\text { change } \\
\text { regression } \\
\text { analysis }\end{array}$ \\
\hline $\begin{array}{l}\text { 10.1016/j.socsc } \\
\text { imed.2015.05. } \\
007\end{array}$ & $\begin{array}{l}\text { Body } \\
\text { impairments }\end{array}$ & $\begin{array}{l}\text { Activity } \\
\text { limitations }\end{array}$ & $\begin{array}{l}\text { Sex } \\
\text { Family } \\
\text { relationships } \\
\text { Walking } \\
\text { stick use }\end{array}$ & $\begin{array}{l}\text { Physical } \\
\text { disabilities }\end{array}$ & $\begin{array}{l}\text { Structural } \\
\text { equation } \\
\text { modelling }\end{array}$ \\
\hline $\begin{array}{l}10.1037 / \mathrm{a} 0035 \\
115\end{array}$ & Depression & $\begin{array}{l}\text { Functional } \\
\text { disability }\end{array}$ & $\begin{array}{l}\text { Social } \\
\text { support }\end{array}$ & $\begin{array}{l}\text { Physical } \\
\text { disabilities }\end{array}$ & $\begin{array}{l}\text { Hierarchical } \\
\text { linear } \\
\text { regressions }\end{array}$ \\
\hline $\begin{array}{l}\text { 10.1093/ageing } \\
\text { /afs106 }\end{array}$ & Diabetes status & $\begin{array}{l}\text { Functional } \\
\text { disability }\end{array}$ & $\begin{array}{l}\text { Physical } \\
\text { activity }\end{array}$ & $\begin{array}{l}\text { Older } \\
\text { adults }\end{array}$ & $\begin{array}{l}\text { Latent growth } \\
\text { curve } \\
\text { modelling }\end{array}$ \\
\hline $\begin{array}{l}10.1111 / \mathrm{j} .1600 \\
- \\
0447.2011 .018 \\
23 . x\end{array}$ & Depression & Disability & $\begin{array}{l}\text { Age } \\
\text { Work stress }\end{array}$ & Depression & $\begin{array}{l}\text { Linear mixed } \\
\text { models }\end{array}$ \\
\hline $\begin{array}{l}10.1111 / \mathrm{j} .1365 \\
- \\
2214.2010 .011 \\
03 . x\end{array}$ & $\begin{array}{l}\text { Behavior } \\
\text { problems }\end{array}$ & Disability & $\begin{array}{l}\text { Parental } \\
\text { attributions } \\
\text { of } \\
\text { controllabilit } \\
\text { y }\end{array}$ & $\begin{array}{l}\text { Children } \\
\text { with } \\
\text { developme } \\
\text { ntal } \\
\text { disabilities }\end{array}$ & $\begin{array}{l}\text { Multivariate } \\
\text { analysis of } \\
\text { variance }\end{array}$ \\
\hline $\begin{array}{l}10.1002 / \text { jclp. } 2 \\
0541\end{array}$ & $\begin{array}{l}\text { Psychosocial } \\
\text { adaptation }\end{array}$ & Disability & $\begin{array}{l}\text { Problem- } \\
\text { solving } \\
\text { Coping }\end{array}$ & $\begin{array}{l}\text { Vietnam } \\
\text { Theater } \\
\text { Veterans }\end{array}$ & $\begin{array}{l}\text { Multiple } \\
\text { regression } \\
\text { analysis }\end{array}$ \\
\hline
\end{tabular}




\begin{tabular}{llllll}
$\begin{array}{l}\text { 10.1016/j.dhjo. } \\
\text { 2013.07.004 }\end{array}$ & $\begin{array}{l}\text { Stigma } \\
\text { perception }\end{array}$ & $\begin{array}{l}\text { Social } \\
\text { avoidance }\end{array}$ & Self-esteem & $\begin{array}{l}\text { Adults } \\
\text { with } \\
\text { disability }\end{array}$ & $\begin{array}{l}\text { Hierarchical } \\
\text { regression } \\
\text { model }\end{array}$ \\
\hline
\end{tabular}

\section{Mediator Variables}

Two approaches or statistical methods are usually used to test the mediation effect: multiple regression and structural equation modelling (path analyses). As we did with moderators, in order to check the use of mediators in the disability field, we conducted another review on the Web of Science (September, 2018). First, we combined the keywords 'mediator' AND 'intellectual disability' in the field 'Title' AND 'program logic model' in the field 'Topic' without any timespan restriction. As expected, the search did not lead to any record. However, using the descriptors 'mediator' AND 'disability' in the field 'Title' without any timespan restriction, the search yielded 71 results - almost three times more results than for moderators. The number is still small when compared with results in other fields, but it can be seen than mediators caught the attention of researchers more frequently and longer ago than the attention paid to moderators. In this sense, researchers seem even more unfamiliar with moderation than mediation. A potential explanation to this issue is that moderators establish that research findings are generalizable across subgroups of population and, if sample size may be an issue in the IDD field, the size of subgroups in people with IDD may be a greater obstacle for testing the effects of moderators. The first article about mediation was published in 1982 and publications have significantly increased in the last five years (39 papers of the 71 articles have been published since 2013). Again, most of the results are from the USA $(n=28)$ and published in English $(n=66)$.

In order to organize the information, we refined the search by adding 'quality of life' as descriptor (i.e., AND 'quality of life' in 'Topic). Actually, also Farmer noticed 
in his systematic review about the use of moderators and mediators in the IDD field (2012) that this type of analyses is more likely to be included in quality of life studies.

The results of our search were reduced to 14 , but two were eliminated for being focused on relatives of people with disability and one because it was not an article and it was not possible to reach the full text or abstract. Thus, as it is summarized in Table 2, the 11 articles that showed mediation relationships frequently used quality of life or a related concept (emotional well-being, participation) as outcomes and disability as predictor or criterion. The most frequently cited mediator was social support, but others such as social competence, disability acceptance, beliefs, positive affect, mental health, proactive coping, stress or health promoting behaviors were also highlighted. In only one case, domains of quality of life were used as the mediator variables.

Table 2. Articles focusing on mediation effects in the disability field.

\begin{tabular}{|c|c|c|c|c|c|}
\hline Reference & $\begin{array}{l}\text { Dependent } \\
\text { Variable }\end{array}$ & $\begin{array}{l}\text { Independent } \\
\text { variable }\end{array}$ & Mediator & Sample & Data analyses \\
\hline $\begin{array}{l}10.1007 / \mathrm{s} 111 \\
36-018-2006- \\
1\end{array}$ & Quality of life & $\begin{array}{l}\text { Functional } \\
\text { disability }\end{array}$ & $\begin{array}{l}\text { Social competence } \\
\text { Disability acceptance } \\
\text { Family support } \\
\text { Support from friends }\end{array}$ & $\begin{array}{l}\text { Adults } \\
\text { with } \\
\text { serious } \\
\text { mental } \\
\text { illness }\end{array}$ & $\begin{array}{l}\text { Simple } \\
\text { regression model }\end{array}$ \\
\hline $\begin{array}{l}\text { 10.1016/j.apn } \\
\text { u.2017.11.01 } \\
2\end{array}$ & $\begin{array}{l}\text { Depressive } \\
\text { symptoms }\end{array}$ & $\begin{array}{l}\text { Physical } \\
\text { disability }\end{array}$ & Social support & Elderly & $\begin{array}{l}\text { Multiple linear } \\
\text { regression } \\
\text { analyses }\end{array}$ \\
\hline $\begin{array}{l}\text { 10.1016/j.bjpt } \\
.2017 .06 .016\end{array}$ & Disability & Depression & $\begin{array}{l}\text { Suffering } \\
\text { Beliefs }\end{array}$ & $\begin{array}{l}\text { Patients } \\
\text { on } \\
\text { physical } \\
\text { therapy }\end{array}$ & $\begin{array}{l}\text { Regression } \\
\text { analyses } \\
\text { PROCESS } \\
\text { macro for SPSS }\end{array}$ \\
\hline $\begin{array}{l}10.1111 / \text { papr. } \\
12449\end{array}$ & $\begin{array}{l}\text { Disability } \\
\text { Quality of life }\end{array}$ & $\begin{array}{l}\text { Pain } \\
\text { catastrophizin } \\
\mathrm{g}\end{array}$ & $\begin{array}{l}\text { Perceived Physical } \\
\text { Activity Decline }\end{array}$ & $\begin{array}{l}\text { Patients } \\
\text { with } \\
\text { diabetes }\end{array}$ & $\begin{array}{l}\text { Multiple linear } \\
\text { regression } \\
\text { analyses }\end{array}$ \\
\hline $\begin{array}{l}\text { Smedema et } \\
\text { al. }(2015)\end{array}$ & $\begin{array}{l}\text { Life } \\
\text { satisfaction }\end{array}$ & $\begin{array}{l}\text { Core self- } \\
\text { evaluations }\end{array}$ & $\begin{array}{l}\text { Perceived stress } \\
\text { Positive affect } \\
\text { Social support }\end{array}$ & $\begin{array}{l}\text { College } \\
\text { students } \\
\text { with } \\
\text { disabilities }\end{array}$ & $\begin{array}{l}\text { Regression } \\
\text { analyses }\end{array}$ \\
\hline $\begin{array}{l}10.1080 / 1360 \\
7863.2014 .95 \\
5457\end{array}$ & Quality of life & $\begin{array}{l}\text { Number of } \\
\text { chronic } \\
\text { conditions }\end{array}$ & $\begin{array}{l}\text { Impairments in } \\
\text { physical body } \\
\text { function } \\
\text { Activity limitations }\end{array}$ & Elderly & $\begin{array}{l}\text { Structural } \\
\text { equation } \\
\text { modelling }\end{array}$ \\
\hline $\begin{array}{l}\text { 10.1016/j.soc } \\
\text { scimed.2015. }\end{array}$ & $\begin{array}{l}\text { Participation } \\
\text { restrictions }\end{array}$ & $\begin{array}{l}\text { Activity } \\
\text { limitations }\end{array}$ & Mental health & $\begin{array}{l}\text { Patients } \\
\text { with knee }\end{array}$ & $\begin{array}{l}\text { Structural } \\
\text { equation }\end{array}$ \\
\hline
\end{tabular}




\begin{tabular}{|c|c|c|c|c|c|}
\hline 05.007 & & & & $\begin{array}{l}\text { osteoarthri } \\
\text { tis }\end{array}$ & modelling \\
\hline $\begin{array}{l}\text { 10.1016/j.rasd } \\
.2012 .12 .009\end{array}$ & $\begin{array}{l}\text { Behavioral } \\
\text { challenges }\end{array}$ & Autistic traits & $\begin{array}{l}\text { Quality of life: } \\
\text { Satisfaction } \\
\text { Competence/Producti } \\
\text { vity } \\
\text { Autonomy/Independe } \\
\text { nce }\end{array}$ & $\begin{array}{l}\text { Adults } \\
\text { with } \\
\text { autism } \\
\text { spectrum } \\
\text { disorders } \\
\text { and } \\
\text { intellectua } \\
\text { 1 disability }\end{array}$ & $\begin{array}{l}\text { Regression } \\
\text { analyses } \\
\text { SPSS macros for } \\
\text { bootstrapping }\end{array}$ \\
\hline $\begin{array}{l}10.1177 / 0034 \\
35521243989 \\
9\end{array}$ & Quality of life & $\begin{array}{l}\text { Functional } \\
\text { disability }\end{array}$ & $\begin{array}{l}\text { Health-promoting } \\
\text { behaviors }\end{array}$ & $\begin{array}{l}\text { Multiple } \\
\text { sclerosis }\end{array}$ & $\begin{array}{l}\text { Hierarchical } \\
\text { regression } \\
\text { analysis } \\
\text { SPSS macros for } \\
\text { bootstrapping }\end{array}$ \\
\hline $\begin{array}{l}10.1002 / \text { da. } 20 \\
481\end{array}$ & Distress & $\begin{array}{l}\text { Functional } \\
\text { disability }\end{array}$ & $\begin{array}{l}\text { Depressive symptoms } \\
\text { Resistance and } \\
\text { attempts to control } \\
\text { symptoms }\end{array}$ & $\begin{array}{l}\text { Obsessive } \\
\text { compulsiv } \\
\text { e disorder }\end{array}$ & $\begin{array}{l}\text { Regression } \\
\text { analyses }\end{array}$ \\
\hline $\begin{array}{l}\text { 문수경 } \\
\text { (2007) }\end{array}$ & $\begin{array}{l}\text { Social } \\
\text { participation }\end{array}$ & $\begin{array}{l}\text { Physical } \\
\text { function }\end{array}$ & Proactive coping & Elderly & $\begin{array}{l}\text { Structural } \\
\text { equation } \\
\text { modelling }\end{array}$ \\
\hline
\end{tabular}

\section{Role of Moderator and Mediator Variables in Theory Development}

As reflected in the previous section, the explanatory and predictive roles that moderator and mediator variables play in program logic models have advanced over the last decades. At the same time, there has emerged a similar interest in — and need forunderstanding better their role in theory development (Cummins 2005; Zuna, Turnbull, \& Summers 2009) and contextual analysis. Identifying contextual factors that affect human functioning and personal outcomes by acting as moderator or mediator variables becomes essential (Shogren, Luckasson, \& Schalock 2014, 2015, 2018a, 2018b, in press). In this section of the article we discuss the role that moderator and mediator variables play in personal outcomes and theory development based on our work in quality of life (Gómez, Verdugo, Arias, \& Arias, 2011; Schalock et al. 2010; Schalock, Verdugo, Gómez, \& Reinders 2016). 
A theory is defined as an integrative construct based on facts and observations that generate hypotheses that can be tested and used as a basis for explanation (Bortolotti 2008; Newton-Smith 2001). A theory, such as one related to individual quality of life, starts with a conceptual model that is used to explain the quality of life concept, integrate current work in the field, and provide the basis for application. Basic to theory development is a conceptual model that organizes knowledge, allows for a common language, and specific components of the quality of life concept without specfiying how the components work. As depicted in Figure 2, our conceptual model of individual quality of life has three components: quality of life domains, moderator and mediator variables (Schalock, Verdugo, Gómez et al. 2016).

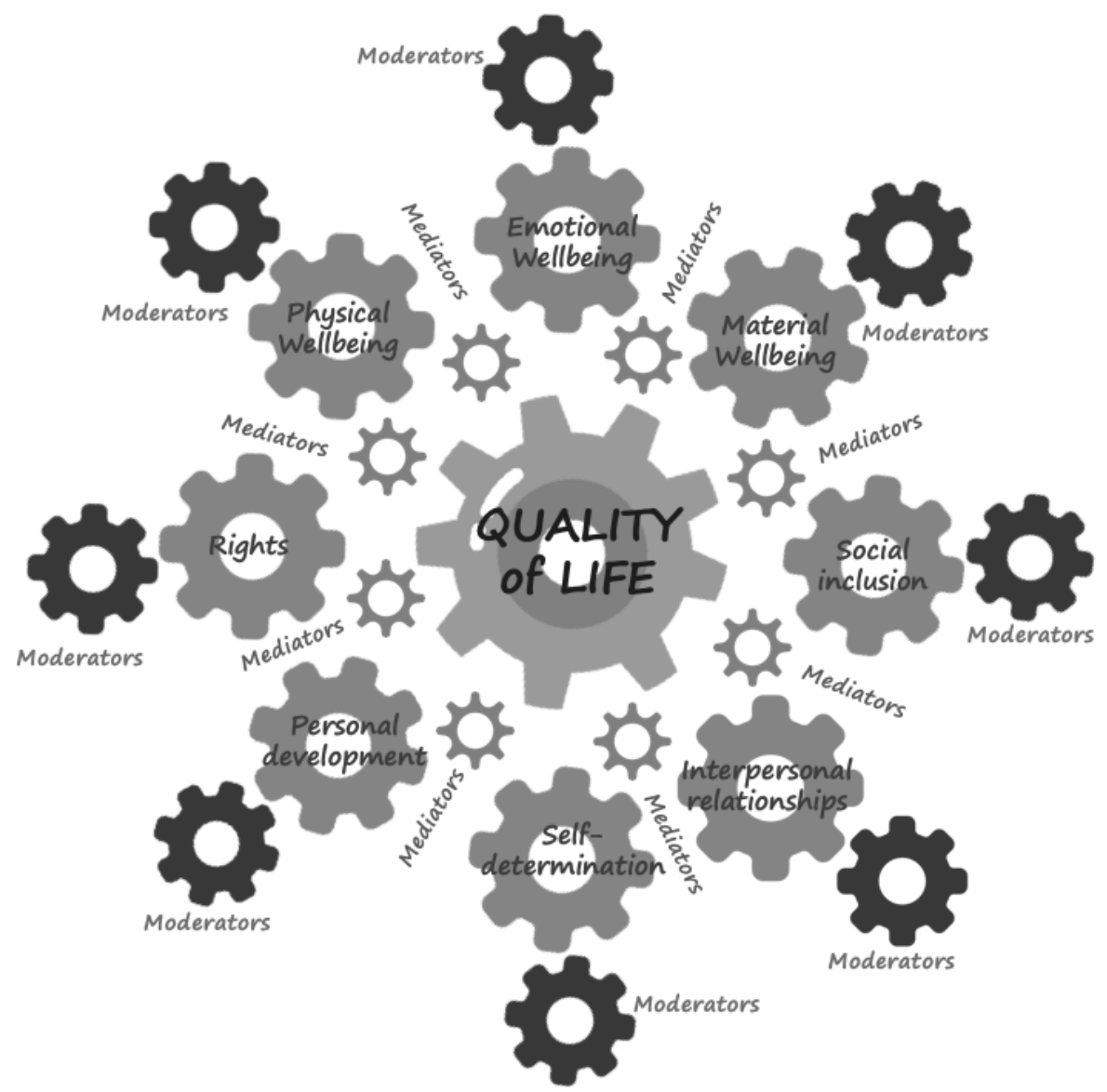

Figure 2. A conceptual model of individual quality of life (adapted from Schalock et al., 2016). 
The conceptual model that is at the heart of Figure 2 presupposes a contextual understanding of disability as a condition that results from interacting individual and environmental factors. This ecological model of disability focuses on personenvironmental interaction, the congruence between personal competence and environmental demands, and opportunities resulting from these interacting factors. In the explanatory component of our theory, these factors are of two kinds: moderating and mediating factors (Schalock, Verdugo, Gómez et al. 2016). An overview of these moderator and mediator variables is presented in Table 3 , including the specific variables studied to date, which are based on the work of Claes et al. (2012); Arias et al. (2018); Donaldson (2007); Felce and Emerson (2001); Gardner and Carran (2005); Gómez, Peña, Arias, and Verdugo (2016); Gómez \& Verdugo (2016); Morán, Gómez, Alcedo, and Pedrosa (2019); Petry and Felce (2005); Schalock and Bonham (2003); Stancliffe, Abery, and Smith (2000); Tassé et al. (2012); Verdugo et al. (in press); Walsh et al. (2010); and Zuna et al. (2010).

Table 3. Potential quality of life moderator and mediator variables and associated variables.

\begin{tabular}{|c|c|c|c|}
\hline System level & Moderators & Mediators & Outcomes \\
\hline Microsystem & $\begin{array}{l}\text { Personal Demographic } \\
\text { Gender } \\
\text { Race } \\
\text { Intellectual functioning } \\
\text { Adaptive behavior } \\
\text { Social economic status } \\
\text { Diagnostic group } \\
\text { Family Unit Factors } \\
\text { Family income, size of family, } \\
\text { family geographical location, } \\
\text { religious preference, family } \\
\text { structure }\end{array}$ & $\begin{array}{l}\text { Personal Status } \\
\text { Residential platform, } \\
\text { employment status, health } \\
\text { status, level of self- } \\
\text { determination and subjective } \\
\text { well-being }\end{array}$ & $\begin{array}{l}\text { Quality of life- } \\
\text { related personal } \\
\text { outcomes }\end{array}$ \\
\hline Mesosystem & $\begin{array}{l}\text { Organization Culture } \\
\text { Level of personal involvement } \\
\text { of the client Level of personal } \\
\text { growth opportunities }\end{array}$ & $\begin{array}{l}\text { Provider System } \\
\text { Individualized supports } \\
\text { Type of services }\end{array}$ & $\begin{array}{l}\text { Quality of life- } \\
\text { related } \\
\text { aggregated } \\
\text { outcomes } \\
\text { (organizational } \\
\text { results in a } \\
\text { QOL measure) }\end{array}$ \\
\hline Macrosystem & $\begin{array}{l}\text { Employment opportunities } \\
\text { Education options }\end{array}$ & $\begin{array}{l}\text { Community Factors } \\
\text { Normative expectations }\end{array}$ & $\begin{array}{l}\text { Quality of life- } \\
\text { related }\end{array}$ \\
\hline
\end{tabular}




\section{A Comprehensive Framework for Incorporating Moderator and Mediator}

\section{Variables into Program Logic Models}

\section{Comprehensive Framework}

Although some significant progress has been made in both developing program logic models such as that shown in Figure 1 and integrative theories such as that shown in Figure 2, more research is needed not only to determine empirically specific relations between the variables stated, but also to identify other potential moderator and mediator variables that may have short-term effects or long-term impacts. To this end, we suggest the need for a comprehensive framework for incorporating moderator and mediator variables into program logic models.

As it depicted in Figure 3, the comprehensive framework of a program logic that incorporates moderator and mediator variables includes four components (input variables, process variables, short term effects, and long term impacts), moderators variables that help answer what an effect depends upon (Farmer, 2012) on input and process variables (e.g., gender or engagement opportunities, respectively)—, mediators —variables that explain how an effect happen (Farmer, 2012) on short-term effects and long-term impact (e.g., material wellbeing or socioecomic position, respectively)—, and specific measures to operationalize the comprehensive framework (e.g., targeted individuals or personal outcomes). On one hand, input and process variables usually include several independent variables, some of which may be potential moderators in the program logic model. On the other hand, short term effects and long-term effects 
usually include dependent variables and outcomes. Some of the process variables and short-term effects may have a role of mediation between independent variables and dependent variables included in the model.

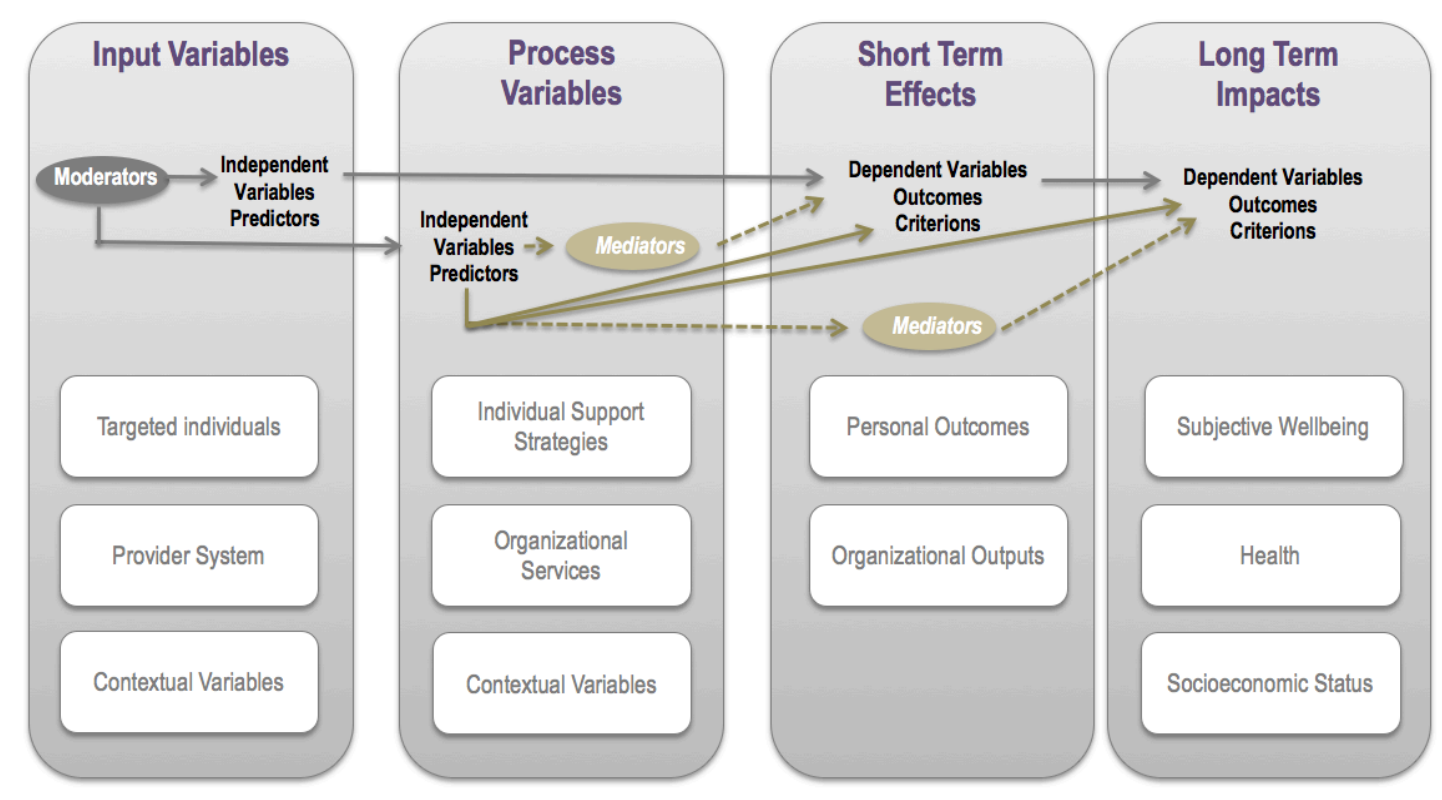

Figure 3. Program logic model that incorporates moderator and mediator variables.

\section{Specific Measures to Operationalize Variables}

Table 4 provides exemplary measures that can be used to operationalize moderator and mediator variables within this comprehensive framework. As summarized in Table 3, associated with each of the four program logic components (input, process, short-term effects, and long-term impacts) the reader will find the respective measurement component and the proposed potential measures/assessments. In this way, the proposed measures in Table 4 for input may be used as potential moderators or independent variables; process variables may be used as independent variables or mediators; short-term effects may be used as dependent variables or mediators; and long-term impacts are used as dependent variables.

Table 4. Specific measures to operationalize the comprehensive framework. 


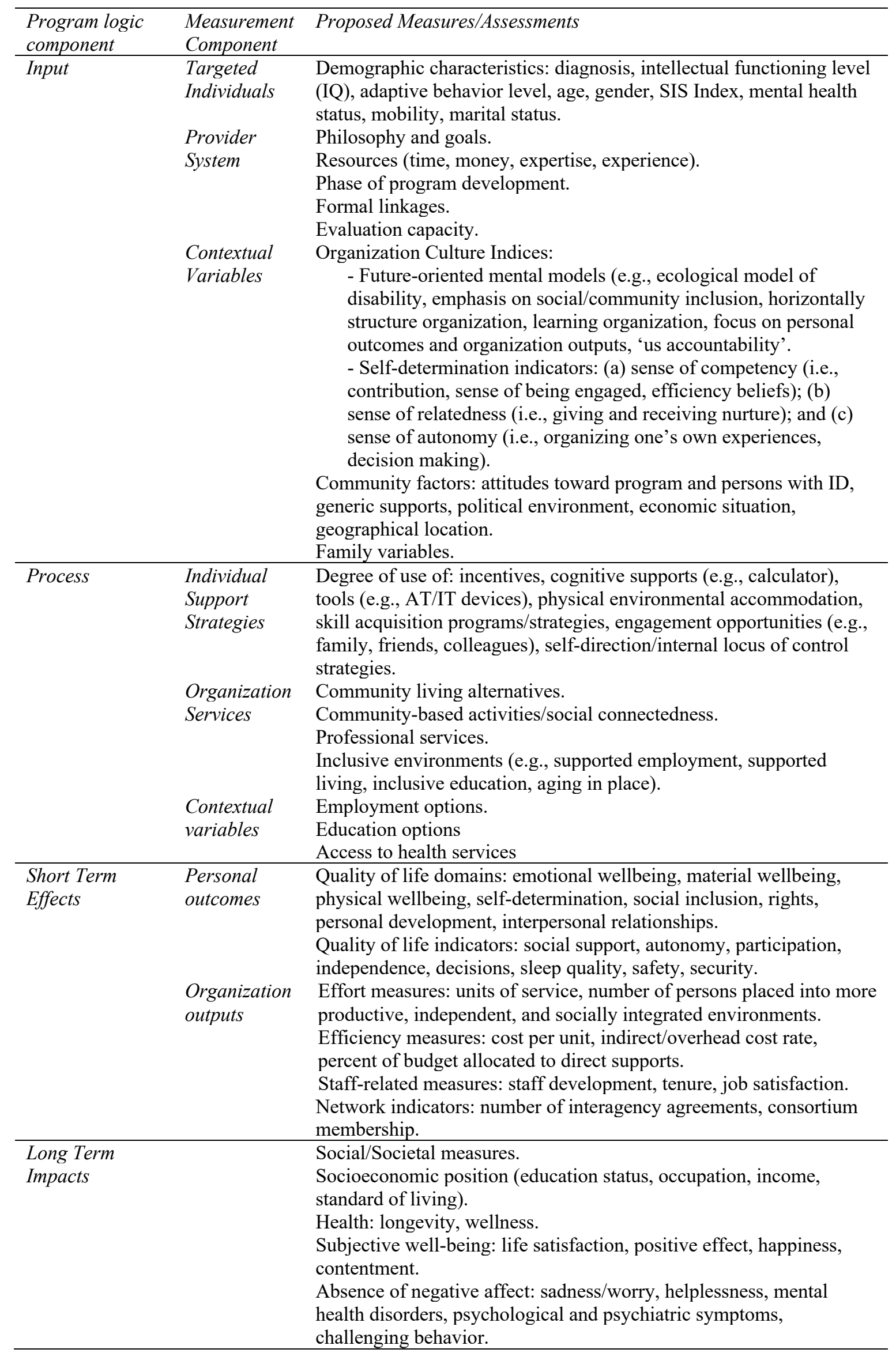




\section{Applying the Framework}

The study of moderators and mediators allow us to obtain a more comprehensive understanding when implementing and evaluating IDD-related policies and practices. However, since testing program logic models that incorporate moderator and/or mediator variables might be very complex statistically, the process should begin by testing specific relations between variables instead of testing the framework as a whole. Thus, we consider that seeking empirical evidence for specific moderation and mediation effects is both preferred and more reasonable than seeking evidence for all the potential relations shown in Figures 2 and 3. The next step would involve examining a number of moderators and mediators. In reference to quality of life research, policies and practices, for example, the examination would involve:

- Level of adaptive behavior (input) might moderate the effect of an intervention (process -independent variable) addressed to enhance quality of life in an organization (short term effect-dependent variable).

- Employment opportunities (process) might moderate the effect of an intervention (process and independent variable) addressed to enhance material wellbeing (short term effect -dependent variable).

- Participation (short term effect) might mediate the relationship between individualized supports (process -independent variable) and interpersonal relationships (short term effect a-dependent variable)

- Social support (personal outcome) might mediate the relationship between environmental accommodations (process -independent variable) and challenging behaviors (long term impact -dependent variable). 
Given that a specific variable (e.g., level of support) may play a different role (e.g., independent variable, dependent variable, moderator, mediator) depending the other variables and the relationships that need to be tested in a specific model, it must be noted that we do not proposed an a priori classification of moderator and variables. As Farmer (2012) advocates, researchers must stablish and state the moderation and mediation effects they want to test together with the exact criteria a variable must fulfill in order to be labelled a moderator or mediator, enhancing in this way quality of the information that we uncover and the services and supports we provide (p. 11).

\section{Future Steps}

We encourage the research community to identify variables that may be act as mediators or moderators of short-term effects and long-term impacts when IDD-related policies and practices are under question. As discussed by MacKinnon (2008), mediators are selected for the most part on the basis of a conceptual model that hypotheses which variables are related to the outcome variable of interest. However, it is also important to use action theory to identify how contextual variables and feedback information mediate these effects and impacts. To facilitate this process, we suggest that researchers, practiotioners, and policy makers identify possible mediators by using qualitative methods (such as focus groups or Delphi methods), and/or use "theorydriven" research and evaluation methods to identify potential mediators such as those listed in Table 1 (Chen 1990; Wasserman 2010). Even more, as it was depicted in Figure 1, when implementing and evaluating practices and policies, it should be noted that moderation of mediated effects are also possible. In this way, for example, gender might moderate the effect of a program to improve social skills or social inclusion (outcome), which in turn, might be mediated by social supports. 
Additionally, researchers, practiotioners, and policy makers need to determine the correlates of the effects or impacts evaluated, which would shed light on the conceptual model used to explain the outcomes. The purpose of this type of research would be to identify variables that are related causally to the outcome and are thus potentially modifiable by an intervention or support strategy. They may not need to know why a variable is related to the outcome variable, but the variable may still be an effective mediator or moderator. This type of research would provide a quantitative measure of associations between moderator or mediator variables and outcome variables.

Farmer (2012) have suggested the use of causal steps only to understand the function of a moderator or mediator, and the use of a direct statistical test to determine their presence. Ideally, this type of study would also include measures of effect size to evaluate the significance of the relation between predictors, mediators and outcome variables. Statistical methods such as partial least square (PLS) regression, which is a very powerful versatile data analytical tool, can be used as a first step to understand the existing relations (Rosipal \& Krämer 2006). Similarly, structural equation modeling (SEM), which allows both confirmatory evidence for theory testing and exploratory modeling for theory development are highly recommended (Bollen,1998). For probing moderators effects, Hayes and Matthes (2009) provide SAS and SPSS syntax, while other helpful calculation tools can be found in Preachers' website (http://www. quantpsy.org). For mediation, MacKinnon (2008), Preacher and Hayes (2004) provide SAS and SPSS macros, while Muthen and Asparouhov (2015) provide scripts for Mplus. Stride, Gardner, Catley, and Thomas (2015) provide Mplus Code for testing different configuration of mediation, moderation and moderated mediation models. Finally, it must be noted that some researchers from other fields are increasingly using 
Bayesian method in the presence of mediation and moderation (Wang \& Preacher, 2014), which can allow for an even more extensive range of models, which can be expressed in terms of logic models. 


\section{Compliance with Ethical Standards}

\section{Ethical Approval}

This article does not contain any studies with human or animal participants performed by any of the authors.

\section{Informed Consent}

As such no informed consent was needed in this study.

\section{Conflict of Interest}

The authors declare that they have no conflict of interest. 


\section{References}

Arias, V. B., Gómez, L. E., Morán, L., Alcedo, M. A., Monsalve, A., \& Fontanil, Y. (2018). Does quality of life differ for children with autism spectrum disorder and intellectual disability compared to children without autism? Journal of Autism and Developmental Disorders, 48(1), 123-136. doi: 10.1007/s10803017-3289-8.

Baron, R. M., \& Kenny, D. A. (1986). The moderator-mediator variable distinction in social psychological research: conceptual, strategic and statistical considerations. Journal of Personality and Social Psychology, 51, 1173-1182. doi: $10.1037 / 0022-3514.51 .6 .1173$

Bollen, K. A. (1998). Structural equation models. New York: Wiley.

Bortolotti, L. (2008). An introduction to the philosophy of science. Malden, MA: Polity. Bradley, J. (2013). When does a conceptual framework become a theory? Reflections from an accidental theorist. Evaluation \& Program Planning, 38, 67-70.

Chen, H. T.(1990). Theory-driven evaluations. Newbury Park, California: Sage.

Chen, H. T. (2004). Practical program evaluation: Assessing and improving planning, implementation, and effectiveness. Thousand Oaks, CA: Sage. doi: $10.1177 / 1356389005055528$

Claes, C., Ferket, N., Vandevelde, S., Verlet, D., \& De Maeyer, J. (2017). Disability Policy Evaluation: Combining Logic Models and Systems Thinking. Intellectual and Developmental Disabilities, 55(4), 247-257. doi:10.1352/19349556-55.4.247

Claes, C., van Hove, G., Vandervelde, S., van Loon, J., \& Schalock, R. L. (2012). The influence of support strategies, environmental factors, and client characteristics 
on quality of life-related outcomes. Research in Developmental Disabilities, 33, 93-103. doi:10.1016/j.ridd.2011.08.024.

Cummins, R. A. (2005). Moving from the quality of life concept to a theory. Journal of Policy and Practice in Intellectual Disabilities, 49, 698-706. doi:

10.1111/j.1365-2788.2005.00738.x

Davies, R. (2004). Scale, complexity and the representation of theories of change. Special Issue: European Evaluation Society Conference, 10(1), 101-121.

De Ruysscher, C., Claes, C., Lee, T., Cui, F., van Loon, J., De Maeyer, J., \& Schalock, R. L. (2017). A Systems Approach to Social Entrepreneurship. Voluntas, 28(6), 2530-2545. doi: 10.1007/s11266-016-9704-5

Donaldson, S. I. (2007). Program theory-driven evaluation science. New York: Lawrence Erlbaum Associates.

Farmer, C. (2012). Demystifying moderators and mediators in intellectual developmental disabilities research: A primer and review of the literature. Journal of Intellectual Disability Research, 56, 1148-1160.

Felce, D., \& Emerson, E. (2001). Living with support in a home in the community: Predictors of behavioral development and household and community activity. Mental Retardation and Developmental Disabilities Research, 34, 23-41. doi: $10.1002 /$ mrdd. 1011

Frazier, P. A., Tix, A. P., \& Barron, K. E. (2004). Testing Moderator and Mediator Effects in Counseling Psychology Research. Journal of Counseling Psychology, 51, 115-134. doi: 10.1037/0022-0167.51.1.115

Gardner, J. F., \& Carran, D. (2005). Attainment of personal outcomes by people with developmental disabilities. Mental Retardation, 43, 157-174. doi: 10.1352/0047-6765(2005)43[157:AOPOBP]2.0.CO;2 
Gómez, L. E., Arias, B., Verdugo, M. A., \& Navas, P. (2012). An outcomes-based assessment of quality of life in social services. Social Indicators Research, 106, 81-93. doi: 10.1007/s11205-011-9794-9

Gómez, L. E., Peña, E., Arias, B., \& Verdugo, M.A. (2016). Impact of individual and organizational variables on quality of life. Social Indicators Research, 125(2), 649-664. doi: 10.1007/s11205-014-0857-6

Gómez, L. E., \& Verdugo, M. A. (2016). Outcomes evaluation. En R. L. Schalock \& K. D. Keith (Eds.), Cross-cultural quality of life: enhancing the lives of persons with intellectual disability (2nd ed.) (pp. 71-80). Washington, DC: American Association on Intellectual and Developmental Disabilities.

Gómez, L. E., Verdugo, M. A., Arias, B., \& Arias, V. (2011). A comparison of alternative models of individual quality of life for social service recipients. Social Indicators Research, 101, 109-126. doi: 10.1007/s11205-010-9639-y

Gómez, L. E., Verdugo, M. A., Arias, B., Navas, P., \& Schalock, R. L. (2013). The development and use of provider profiles at the organization and systems level. Evaluation \& Program Planning, 40, 17-26. doi: 10.1016/j.evalprogplan.2013.05.001

Hair, J. F., Black, B., Babin, B., J., Anderson, R. E., \& Tatham, R. L. (2006). Multivariate Data Analysis (6th Ed.). Upper Saddle River, New Jersey: Pearson Education Inc.

Hansen, M., Alkin, M. C., \& Wallace, T. L. (2013). Depicting the logic of three evaluation theories. Evaluation and Program Planning, 38, 34-43. doi:10.1016/j.evalprogplan.2012.03.012 
Hayes A., \& Matthes J. (2009). Computational procedures for probing interactions in OLS and logistic regression: SPSS and SAS implementations. Behavior Research Methods, 41, 924-36.

Hayes, A. F., Montoya, A. K., \& Rockwood, N. J. (2017). The analysis of mechanisms and their contingencies: PROCESS versus structural equation modeling. Australasian Marketing Journal, 25, 76-81. doi:10.1016/j.ausmj.2017.02.001

Kaplan, S. A., \& Garrett, K. E. (2005). The use of logic models by community-based initiatives. Evaluation \& Program Planning, 28, 167-172. doi:10.1016/j.evalprogplan. 2004.09.002

MacKinnon, D. P. (2008). Introduction to statistical mediation analysis. New York: Erlbaum.

MacKinnon, D. P. (2011). Integrating Mediators and Moderators in Research Design. Research on Social Work Practice, 21(6), 675-681. doi: $10.1177 / 1049731511414148$

Mark, M. M. (2008). Building a better evidence base for evaluation theory: Beyond general calls to a framework of types of research on evaluation. In N. L. Smith \& P. Brandon (Eds.), Fundamental issues in evaluation (pp. 111-134). New York, NY: Guilford Press

Millar, A., Simeone, R. S., \& Carnevale, J.T. (2001). Logic models: A systems tool for performance management. Evaluation and Program Planning, 24(1), 73-81. doi:10.1016/S0149-7189(00)00048-3

Morán, L., Gómez, L. E., Malcedo, M.A., \& Pedrosa, N. (2019). Gender differences in social inclusion of youth with autism and intellectual disability. Journal of Autism and Developmental Disorders, 49, 2980-2989. doi:10.1007/s10803019-04030-z 
Muthén, B., \& Asparouhov, T. (2015). Causal Effects in Mediation Modeling: An Introduction With Applications to Latent Variables. Structural Equation Modeling: A Multidisciplinary Journal, 22(1), 12-23. doi:

$10.1080 / 10705511.2014 .935843$

Newton-Smith, W. H. (Ed.) (2001). A companion to the philosophy of science. London, UK: Blackwell.

Owen, J. M. (2006). Program evaluation: Forms and approaches. Sydney: Allen and Unwin.

Perry, J., \& Felce, D. (2005). Factors associated with outcomes in community group homes. American Journal on Mental Retardation, 110, 121-135. doi: 10.1352/0895-8017(2005)110<121:FAWOIC >2.0.CO;2

Preacher K., \& Hayes A. (2004). SPSS and SAS procedures for estimating indirect effects in simple mediation models. Behavior Research Methods, Instruments, and Computers, 36, 717-31.

Rogers, P. J. (2008). Using programme theory to evaluate complicated and complex aspects of interventions. Evaluation, 14(1), 29-48.

Rosipal, R., \& Krämer, N. (2006). Overview and recent advances in partial least squares. In C. Saunders, M. Grobelnik, S. Gunn, \& J. Shawe-Taylor (eds.), Subspace, Latent Structure and Feature Selection (pp. 34-51). Berlin: Springer.

Schalock, R. L. (2018). Seis ideas que están cambiando el campo de las discapacidades intelectuales y del desarrollo en todo el mundo [Six Ideas That Are Changing the IDD Field Internationally]. Siglo Cero, 49(1), 7-19.

Schalock, R. L., \& Bonham, G. S. (2003). Measuring outcomes and managing for results. Evaluation and Program Planning, 26(3), 229-235. doi:10.1016/S0149-7189(03)00027-2 
Schalock, R. L., Keith, K. D., Verdugo, M. A., \& Gomez, L. E. (2010). Quality of life model development and use in the field of intellectual disability. In R. Kober (ed.), Enhancing the quality of life of people with intellectual disabilities: From theory to practice (pp. 17-32). New York: Springer.

Schalock, R. L., Thompson, J.R., \& Tassé, M.J. (2018). A systematic approach to personal support plans. Washington, DC: American Association on Intellectual and Developmental Disabilities.

Schalock, R. L., \& Verdugo, M. A. (2012a). A leadership guide for today's disabilities organizations: Overcoming challenges and making change happen. Baltimore: Brookes.

Schalock, R. L., \& Verdugo, M. A. (2012b). A conceptual and measurement framework to guide policy development and systems change. Journal of Policy and Practice in Intellectual Disabilities, 9, 63-72.

Schalock, R. L., \& Verdugo, M. A. (2013). The transformation of disabilities organizations. Intellectual and Developmental Disabilities, 51, 273-286.

Schalock, R. L., Verdugo, M. A. y Gómez, L. E. (2011). Evidence-based practices in the field of intellectual and developmental disabilities: An international consensus approach. Evaluation and Program Planning, 34, 273-282. doi:10.1016/j.evalprogplan.2010.10.004

Schalock, R. L., Verdugo, M. A., \& Gómez, L. E. (2017). Translating the quality of life concept into practice. In N. Singh, M. L. Wehmeyer \& K. Shogren (eds.), Handbook of Positive Psychology in Intellectual and Developmental Disabilities: Translating Research into Practice (pp. 115-126). New York: Springer. 
Schalock, R. L., Verdugo, M. A., Gómez, L. E., \& Reinders, H. S. (2016). Moving us toward a theory of individual quality of life. American Journal on Intellectual and Developmental Disabilities, 121, 1-12. Doi:10.1352/1944-7558-121.1.1

Schalock, R. L., Verdugo, M. A., \& Lee. T. (2016). A systematic approach to an organization's sustainability. Evaluation and Program Planning, 56, 56-63. 10.1016/j.evalprogplan.2016.03.005

Schalock, R. L., Verdugo, M. A., \& van Loon, J. (2018). Understanding organization transformation in evaluation and program planning. Evaluation and Program Planning, 67, 53-60.

Shogren, K. A., Luckasson, R., \& Schalock, R. L. (2014). The definition of context and its application in the field of intellectual disability. Journal of Policy and Practice in Intellectual Disabilities, 11, 109-116. doi:10.1111/jppi.12077

Shogren, K. A., Luckasson, R., \& Schalock, R. L. (2015). Using context as an integrative framework to align policy goals, supports, and outcomes in intellectual disability. Intellectual and Developmental Disabilities, 53, 367376. doi:10.1352/1934-9556-53.5.367

Shogren, K. A., Luckasson, R., \& Schalock, R. L. (2017) An Integrated Approach to Disability Policy Development, Implementation, and Evaluation. Intellectual and Developmental Disabilities, 55(4), 258-268. doi: 10.1352/1934-955655.4 .258

Shogren, K. A., Luckasson, R., \& Schalock, R. L. (2018a). The Responsibility to build contexts that enhance human functioning and promote valued outcomes for people with intellectual disability: Strengthening system responsiveness. Intellectual and Developmental Disabilities, 56, 287-300. doi: 10.1352/1934$9556-56.5 .287$ 
Shogren, K. A., Luckasson, R., \& Schalock, R. L. (2018b). The use of a context-based change model to unfreeze the status quo and drive valued outcomes. Journal of Policy and Practice in Intellectual Disabilities, 15, 101-109. doi:10.1111/jppi.12233

Shogren, K. A., Luckasson, R., \& Schalock, R. L. (in press). Using a MultiDimensional Model to Analyze Context and Enhance Personal Outcomes. Intellectual and Developmental Disabilities. Retrieved from http://aaidd.org/docs/default-source/default-documentlibrary/shogren2.pdf?sfvrsn=6b8e3621_0

Stancliffe, R., Abery, B., \& Smith, J. (2000). Personal control and the ecology of community living settings: Beyond living unit size and type. American Journal on Mental Retardation, 105(6), 431-454. doi: 10.1352/08958017(2000)105<0431:PCATEO >2.0.CO;2

Stride, C.B., Gardner, S.E., Catley, N., \& Thomas, F. (2015). Mplus Code for Mediation, Moderation and Moderated Mediation Models. Available at http://www.offbeat.group.shef.ac.uk/FIO/models_and_index.pdf

Tassé, M. J., Schalock, R. L., Balboni, G., Bersani, H. J., Borthwick-Duffy, S. A., Spreat, S., ..., \& Zhang, D. (2012). The construct of adaptive behavior: its conceptualization, measurement, and use in the field of intellectual disability. American Journal of Intellectual and Developmental Disabilities, 117(4), 291303. doi: 10.1352/1944-7558-117.4.291

Taylor-Powell, E., \& Henert, E. (2008). Developing a logic model: Teaching and training guide. Madison: University of Wisconsin-Extension. Retrieved from http://www.uwex.edu/ces/pdande/evaluation/pdf/lmguidecomplete.pdf. 
Verdugo, M. A. (2018). Conceptos clave que explican los cambios en las discapacidades intelectuales y del desarrollo en España [Key concepts and principles that explain changes in the provision of supports for intellectual and developmental disabilities in Spain]. Siglo Cero, 49(1), 35-52.

Verdugo, M.A., Fernández, M., Gómez, L.E., Amor, A., \& Aza, A. (in press). Predictive factors of quality of life in acquired brain injury. International Journal of Clinical and Health Psychology. doi: 10.1016/j.ijchp.2019.06.004

Verdugo, M. A., Jenaro, C., Calvo. I., \& Navs, P. (2017). Disability policy implementation from a cross-cultural perspective. Intellectual and Developmental Disabilities, 55(4), 234-246.

Verdugo, M.A., Navas, P., Gómez, L.E., \& Schalock, R.L. (2012). The concept of quality of life and its role in enhancing human rights in the field of intellectual disability. Journal of Intellectual Disability Research, 56(2), 1036-1045. doi: $10.1111 / \mathrm{j} .1365-2788.2012 .01585 . \mathrm{x}$

Walsh, P. N., Emerson, E. Lobb, C., Hatton, C., Bradley, V., Schalock, R. L., \& Moseley, C. (2010). Supported accommodation for people with intellectual disabilities and quality of life: An overview. Journal of Policy and Practices in Intellectual Disabilities, 7, 137-142.

Wang, L. \&, Preacher, K. J. (2014). Moderated Mediation Analysis Using Bayesian Methods. Structural Equation Modeling: A Multidisciplinary Journal, 22(2), 249-263. doi 10.1080/10705511.2014.935256

Wasserman, D. L. (2010). Using a systems orientation and foundational theory to enhance theory-driven human service program evaluations. Evaluation and Program Planning, 33(2), 67-80. doi:10.1016/j.evalprogplan.2009.06.005 
Zuna, N. I., Turnbull, A., \& Summers, J. A. (2009). Family quality of life: Moving from measurement to application. Journal of Policy and Practices in Intellectual Disabilities, 6, 25-31. 